\title{
Diversity and Composition of Tropical Metropolitan ants (Hymenoptera: Formicidae): An Indicator to Urban Biodiversity and Ecosystem Health
}

\author{
Amira Aqilah Muhammad \\ Universiti Malaya \\ Nurul Ashikin Abdullah ( $\nabla$ shikin84@um.edu.my) \\ Universiti Malaya https://orcid.org/0000-0002-1111-2732 \\ Zubaidah Ya'cob \\ Universiti Malaya \\ Mohammad Saiful Mansor \\ Universiti Kebangsaan Malaysia
}

\section{Research Article}

Keywords: urban ecology, functional group, invasive species, Kuala Lumpur, Peninsular Malaysia.

Posted Date: February 1st, 2022

DOI: https://doi.org/10.21203/rs.3.rs-707107/v1

License: (a) (i) This work is licensed under a Creative Commons Attribution 4.0 International License. Read Full License 


\section{Abstract}

Ant communities are highly sensitive to niche changes; therefore, they are useful indicators of ecosystem health. Little to nothing is known about ant communities inhabiting Kuala Lumpur's metropolitan parks. Therefore, we aimed to survey ant species diversity and composition in 12 parks within the Federal Territory of Kuala Lumpur, Malaysia. Forty-nine species from 29 genera and six subfamilies were identified from 9,677 individuals in 1,008 field collections, made using a combination of hand-collection and pitfall and yellow pan methods, from February to July 2019. The species accumulation curve reached a plateau after approximately 80 samplings. The difference in ant diversity between parks was nonsignificant. The dominant ant species was Oecophylla smaragdina, followed by Carebara diversa and Anoplolepis gracilipes. This study provides the first ant checklist, comprising information on eight functional groups, seven invasive and several forest-associated species, and one new locality record, for highly urbanized areas in Peninsular Malaysia. Our results provide a basis for future studies to better understand the potential consequences of urbanization on ant communities and their ecology in urban settings.

\section{Introduction}

Malaysia, one of the 12 megadiverse countries of the world, is a developing and urbanizing

Nation (Malaysia Biodiversity Information System, 2015). With extremely rapid population growth, from 6.5 million in 1957 to 32.7 million in 2020 (Department of Statistics Malaysia, 2020), Malaysia has undergone substantial urbanization and degradation of its natural tropical landscapes. The proportion of Malaysia's urban population grew rapidly from $28.4 \%$ in 1970 to $62 \%$ in 2000 (Yaakob et al., 2010); as of 2019 , more than $75 \%$ of the population are living in urban areas (O'Neill, 2021). Nevertheless, biodiversity and ecology are still undervalued in the cities' development.

Urbanization generates a cascade of secondary effects on habitat quality, including increased fragmentation, exposure to habitat edge effects, and introduction of non-native species (Marshall \& Shortle, 2005). Consequently, it poses a significant threat to biodiversity (Fattorini, 2016). Therefore, the study of urban biodiversity is crucial not only for the purposes of recreation and wellbeing but also for conservation (Andersson et al., 2015).

Arthropods inhabiting urban green areas experience different outcomes (positive or negative) depending on a range of factors (Mclntyre, 2000). Urban parks in central Brazil have been ranked the highest for conservation value compared to other types of urban green spaces as they support the most ant species, primarily native taxa. However, the abundance of specialist insects are reported to decline due to urbanization; herbivorous, parasitic, saprophagous, and flower-visiting insects are much more negatively affected by urbanization than predatory insects (Ye et al., 2013). In contrast, some generalist taxa, including aphids, cockroaches, and termites, may increase in abundance (Santos, 2016). 
Ants serve as ideal ecological indicators of changes in the environment (Andersen, 1999; Brown, 1997; Kremen, 1992; Lawes et al., 2005; McGeoch, 1998; Santos, 2016; Uehara-Prado et al., 2009). Ant community patterns reflect the status and quality of their habitats, which range from natural forest to disturbed ecosystems/habitats (Andersen et al., 2003; Andersen \& Mayer, 2004; Folgarait, 1998; Koch \& Vohland, 2008; Underwood \& Fisher, 2006). Ants yield vital information on intensification and/or rehabilitation processes in agroecosystems at low cost and within a relatively short time (Underwood \& Fisher, 2006). In urban environments, they also serve as food sources for reptiles, birds, and mammals, which are highly dependent on the limited natural food resources in these habitats.

More than 800 ant species are reported from Malaysia. Of these, 23 are classified as urban pest species (Na \& Lee, 2001). Locally, most ant studies have been conducted in natural forest (Abdullah \& Hashim, 2010; Malsch et al., 2003; Mustafa et al., 2011; Noor-Izwan \& Amirrudin, 2014). Little to nothing is known about metropolitan ants. Only a few ant checklists are available for the urban parts of Penang, but they are mostly focused on household pest species (Ab-Majid et al., 2016; Norasmah et al., 2006; Yap \& Lee, 1994). Therefore, this study aims to comprehensively explore the diversity and composition of ants inhabiting metropolitan parks within the Federal Territory of Kuala Lumpur. The results of this study will provide baseline data to help predict the roles and functions of ants in urban development and ensure that urban expansion proceeds sustainably.

\section{Methodology}

\section{Study site}

Detail and map of sampling locations across Federal Territory of Kuala Lumpur is presented in Table 1 and Fig. 1. Kuala Lumpur, or officially known as Federal Territory of Kuala Lumpur, is the country's national capital which is located in the west of Peninsular Malaysia in the middle of the state of Selangor. Covering an area of $243 \mathrm{~km}^{2}$, the population is estimated 1.79 million as of 2018 (Dept. of Statistics Malaysia, 2020). The climate is tropical, hot and humid all over the year with minimum and maximum of the temperature estimated around $23^{\circ} \mathrm{C}$ and $35^{\circ} \mathrm{C}$ with annual rainfall of $2600 \mathrm{~mm}$. 
Table 1

Details of sampling location conducted at 12 urban parks around the federal territory of Kuala Lumpur, Malaysia.

\begin{tabular}{|c|c|c|c|c|c|}
\hline Code & Location & GPS coordinates & Constituency & $\begin{array}{l}\text { Park size* } \\
\text { (ha) }\end{array}$ & $\begin{array}{l}\text { Elevation } \\
\text { range } \\
\text { (m.a.s.l) }\end{array}$ \\
\hline TAD & $\begin{array}{l}\text { Taman Rekreasi Alam } \\
\text { Damai }\end{array}$ & $\begin{array}{l}3.0677^{\circ} \mathrm{N} \\
101.7404^{\circ} \mathrm{E}\end{array}$ & $\begin{array}{l}\text { Bandar Tun } \\
\text { Razak }\end{array}$ & 9.5 & $76-113$ \\
\hline TAH & $\begin{array}{l}\text { Taman Tasik Ampang } \\
\text { Hilir }\end{array}$ & $\begin{array}{l}3.1539^{\circ} \mathrm{N} \\
101.7446^{\circ} \mathrm{E}\end{array}$ & Titiwangsa & 16.0 & $39-44$ \\
\hline TAK & $\begin{array}{l}\text { Taman Awam Bukit } \\
\text { Kiara }\end{array}$ & $\begin{array}{l}3.1385^{\circ} \mathrm{N}, \\
101.6326^{\circ} \mathrm{E}\end{array}$ & Segambut & 5.9 & $61-79$ \\
\hline TBJ & $\begin{array}{l}\text { Taman Rekreasi Bukit } \\
\text { Jalil }\end{array}$ & $\begin{array}{l}3.0528^{\circ} \mathrm{N} \\
101.6753^{\circ} \mathrm{E}\end{array}$ & Seputeh & 20.2 & $54-82$ \\
\hline TBP & Taman Botani Perdana & $\begin{array}{l}3.14344^{\circ} \mathrm{N} \\
101.6845^{\circ} \mathrm{E}\end{array}$ & Segambut & 91.6 & $33-75$ \\
\hline TDB & Taman Dusun Bandar & $\begin{array}{l}3.1296^{\circ} \mathrm{N} \\
101.6941^{\circ} \mathrm{E}\end{array}$ & Bukit Bintang & 7.7 & $48-55$ \\
\hline TDK & $\begin{array}{l}\text { Taman Tasik Datuk } \\
\text { Keramat }\end{array}$ & $\begin{array}{l}3.1683^{\circ} \mathrm{N} \\
101.7340^{\circ} \mathrm{E}\end{array}$ & Setiawangsa & 6.0 & $26-47$ \\
\hline TMB & $\begin{array}{l}\text { Taman Metropolitan } \\
\text { Batu }\end{array}$ & $\begin{array}{l}3.2139^{\circ} \mathrm{N}, \\
101.6792^{\circ} \mathrm{E}\end{array}$ & Batu & 113.3 & $43-46$ \\
\hline TMK & $\begin{array}{l}\text { Taman Metropolitan } \\
\text { Kepong }\end{array}$ & $\begin{array}{l}3.2236^{\circ} \mathrm{N} \\
101.6456^{\circ} \mathrm{E}\end{array}$ & Kepong & 88.6 & $55-88$ \\
\hline TPU & $\begin{array}{l}\text { Taman Rekreasi Pudu } \\
\text { Ulu }\end{array}$ & $\begin{array}{l}3.1240^{\circ} \mathrm{N} \\
101.7334^{\circ} \mathrm{E}\end{array}$ & Cheras & 25.9 & $51-57$ \\
\hline TTM & $\begin{array}{l}\text { Taman Tasik } \\
\text { Menjalara }\end{array}$ & $\begin{array}{l}3.19400^{\circ} \mathrm{N} \\
101.6273^{\circ} \mathrm{E}\end{array}$ & Segambut & 10.6 & $92-116$ \\
\hline TTP & $\begin{array}{l}\text { Taman Tasik } \\
\text { Permaisuri }\end{array}$ & $\begin{array}{l}3.0958^{\circ} \mathrm{N} \\
101.7199^{\circ} \mathrm{E}\end{array}$ & $\begin{array}{l}\text { Bandar Tun } \\
\text { Razak }\end{array}$ & 49.4 & $39-61$ \\
\hline
\end{tabular}

\section{Field sampling}

A total of 1,008 collections were conducted between February to July 2019 ( 28 for each transects at 12 urban parks). To maximise the sample collection, three collection methods, hand-picking, pitfall trapping, and yellow pan trapping were conducted along three $100 \mathrm{~m}$ line transects at $10 \mathrm{~m}$ points interval. At each point for hand-picking, ants were sampled in a 1-metre squared plot for a maximum of 10 minutes per plot. Ants found on trees, ground, roads and pavements were hand-picked by one person using featherweight forceps. For pitfall and yellow-pan traps, trapping solution containing distilled water, fine 
salt and dishwashing liquid were used (Grootaert et al., 2010). Nine traps each for the pitfall and yellowpan were set up along the dedicated line transect and left for three consecutive days. Trapped samples were stored in universal bottles containing $70 \%$ ethanol and brought back to the laboratory for further sorting, preservation and identification. Identification was based on online ant identification database (AntWeb v8.1.5; AntWiki.org; Antbase.net) and published papers (Akbar \& Bharti, 2017; Bharti \& Silla, 2011; Bharti \& Wachkoo, 2013; Eguchi, 2001; Fayle et al., 2014; Heterick \& Shattuck, 2011; Karmaly, 2004; $\mathrm{Na} \&$ Lee, 2001; Pfeiffer et al., 2011). Ants were categorised according to their functional groups according to Andersen (2000) and Brown (2000).

\section{Data analysis}

Each species was subjected to frequency of occurrence (FO), presented in percentage, calculated by the total number of a species occurrence divided by the total number of collections ( $n=1008)$, and as well as site occurrence (SO), calculated by the number of sites where a species was taken divided by the total sites $(n=12)$ were calculated in percentages (Ya'cob et al., 2016). The abundance distribution of ants from each park were tested for their fit to the log series model. Sampling efficiency was obtained from species richness estimators and species accumulation curves. The mean of all estimators involved (Chao, Jack 1, Jack 2, Bootstrap) was calculated and compared with the observed species for an easier assessment of sampling efficiency. Species accumulation curves were plotted based on sample-based dataset. Diversity and richness indices were also calculated. For a-diversity, the indices used are Shannon-Weiner diversity index $\left(H^{\prime}\right)$, Simpson's (D), and Evenness J. For $\beta$-diversity comparison, BrayCurtis dissimilarity index was used as a quantitative measure between communities experiencing changing environments. Normality tests were performed using Shapiro-Wilk (W) at $95 \%$ confidence level $(p \leq 0.05)$. Data were not normally distributed and therefore Kruskal-Wallis was used to test the significance different between number of species and abundance at all sites. All calculations and plots were done using "vegan" and "ggplot2" packages in software RStudio version 1.2.5033 (R Core Team, 2020). Additionally, the ants collected were classified into functional groups and invasiveness status.

\section{Results}

\section{Species composition}

Forty-nine species of ants were collected in a total of 1,008 samples from 12 urban parks in Kuala Lumpur (Tables 2 and 3). The most frequently collected species (FO) were Oecophylla smaragdina (22.6\%), Odontoponera denticulata (19.6\%) and Camponotus (Tanaemyrmex) sp.1 (18.6\%). Relatively common species were Camponotus sp.1 (13.9\%), Tetramorium smithi (13.4\%), Diacamma rugosum $(13.3 \%)$ and Anoplolepis gracilipes (11.8\%). Other species were collected at a frequency lower than $10 \%$. In term of total individuals collected, Oecophylla smaragdina, was the most abundant species (20\%) while the others were collected at lower than 10\%. Based on site occurrence (SO), Camponotus sp.1, Camponotus (Tanaemyrmex) sp.1, Cardiocondyla sp., Monomorium orientale, and Pheidole parva were collected at all urban parks (12 sites). However, thirteen (13) ant species, including Crematogaster quadriruga and Philidris sp., were collected only at one park. 
Table 2

Total individual, frequency (FO) and site (SO) occurrences, functional group (FG) and invasive status of two most abundant ant subfamilies collected at 12 urban parks inside the Federal Territory of Kuala Lumpur, Malaysia.

\begin{tabular}{|c|c|c|c|c|c|c|}
\hline \multirow[t]{2}{*}{ Subfamily } & \multirow[t]{2}{*}{ Species $(n=32)$} & \multirow{2}{*}{$\begin{array}{l}\text { Total } \\
\text { specimen }\end{array}$} & \multicolumn{2}{|c|}{$\begin{array}{l}\text { Percentage } \\
(\%)\end{array}$} & \multirow[t]{2}{*}{ FG } & \multirow[t]{2}{*}{$\begin{array}{l}\text { Invasive } \\
\text { Status* }\end{array}$} \\
\hline & & & FO & so & & \\
\hline \multirow[t]{11}{*}{ Formicinae } & Anoplolepis gracilipes & 728 & 11.8 & 58.3 & TCS & Yes \\
\hline & Camponotus sp. 1 & 222 & 13.9 & 100 & SC & No \\
\hline & Camponotus sp. 2 & 2 & 0.2 & 8.3 & SC & No \\
\hline & $\begin{array}{l}\text { Camponotus (Tanaemyrmex) } \\
\text { sp.1 }\end{array}$ & 529 & 18.6 & 100 & SC & No \\
\hline & Nylanderia sp.1 & 6 & 0.4 & 33.3 & 0 & No \\
\hline & Nylanderia sp.2 & 80 & 3.6 & 41.7 & 0 & No \\
\hline & Oecophylla smaragdina & 1939 & 22.6 & 83.3 & TCS & No \\
\hline & Paratrechina longicornis & 461 & 12.2 & 91.7 & 0 & Yes \\
\hline & Polyrhachis abdominalis & 12 & 1.1 & 41.7 & SC & No \\
\hline & Polyrhachis proxima & 10 & 0.7 & 25.0 & SC & No \\
\hline & Polyrhachis sp. & 1 & 0.1 & 8.3 & SC & No \\
\hline \multirow[t]{13}{*}{ Myrmicinae } & Cardiocondyla sp. & 268 & 8.3 & 100 & 0 & No \\
\hline & Carebara affinis & 93 & 2.2 & 58.3 & C & No \\
\hline & Carebara diversa & 882 & 4.0 & 41.7 & C & No \\
\hline & Crematogaster quadriruga & 24 & 0.5 & 8.3 & GM & No \\
\hline & Crematogaster sewardi & 25 & 0.4 & 16.7 & GM & No \\
\hline & Crematogaster treubi & 60 & 2.5 & 66.7 & GM & No \\
\hline & Meranoplus bicolor & 81 & 3.3 & 83.3 & HCS & No \\
\hline & Monomorium floricola & 20 & 1.2 & 33.3 & GM & Yes \\
\hline & Monomorium orientale & 395 & 7.6 & 100 & GM & No \\
\hline & Monomorium pharaonis & 20 & 0.9 & 25.0 & GM & Yes \\
\hline & Pheidole cariniceps & 6 & 0.2 & 8.3 & GM & No \\
\hline & Pheidole megacephala & 154 & 1.1 & 16.7 & GM & Yes \\
\hline & Pheidole parva & 620 & 15 & 100 & GM & No \\
\hline
\end{tabular}




\begin{tabular}{llllll|} 
Proatta butteli & 1 & 0.1 & 8.3 & TCS & No \\
\hline Solenopsis sp. & 1 & 0.1 & 8.3 & TCS & No \\
\hline Strumigenys sp. & 1 & 0.1 & 8.3 & C & No \\
\hline Tetramorium bicarinatum & 74 & 2.3 & 25.0 & 0 & No \\
\hline Tetramorium lanuginosum & 309 & 5.7 & 83.3 & 0 & No \\
\hline Tetramorium pacificum & 13 & 1.1 & 41.7 & 0 & No \\
\hline Tetramorium smithi & 673 & 13.4 & 83.3 & 0 & No \\
\hline Tetramorium walshi & 0 & 2 & 25.0 & 0 & No \\
\hline
\end{tabular}


Table 3

Total individual, frequency (FO) and site (SO) occurrences, functional group (FG) and invasive status of four ant subfamilies with less than 10 species collected from 12 urban parks inside the Federal Territory of Kuala Lumpur, Malaysia.

\begin{tabular}{|c|c|c|c|c|c|c|}
\hline \multirow[t]{2}{*}{ Subfamily } & \multirow[t]{2}{*}{ Species $(n=17)$} & \multirow[t]{2}{*}{$\begin{array}{l}\text { Total } \\
\text { specimen }\end{array}$} & \multicolumn{2}{|c|}{$\begin{array}{l}\text { Percentage } \\
\text { (\%) }\end{array}$} & \multirow[t]{2}{*}{ FG } & \multirow[t]{2}{*}{$\begin{array}{l}\text { Invasive } \\
\text { Status* }\end{array}$} \\
\hline & & & FO & so & & \\
\hline Ectatomminae & Gnamptogenys sp. & 2 & 0.2 & 8.3 & TCS & No \\
\hline \multirow[t]{3}{*}{ Pseudomyrmicinae } & Tetraponera pilosa & 1 & 0.1 & 8.3 & TCS & No \\
\hline & Tetraponera rufonigra & 1 & 2.1 & 33.3 & TCS & No \\
\hline & Tetraponera sp. & 66 & 0.1 & 8.3 & TCS & No \\
\hline \multirow[t]{6}{*}{ Dolichoderinae } & Dolichoderus thoracicus & 638 & 10.2 & 50 & TCS & No \\
\hline & $\begin{array}{l}\text { Dolichoderus thoracicus } \\
\text { rufescens }\end{array}$ & 3 & 0.1 & 8 & TCS & No \\
\hline & Iridomyrmex anceps & 74 & 2.2 & 41.7 & DD & No \\
\hline & Philidris sp. & 38 & 0.7 & 8.3 & DD & No \\
\hline & $\begin{array}{l}\text { Tapinoma } \\
\text { melanocephalum }\end{array}$ & 288 & 10.2 & 100 & 0 & Yes \\
\hline & Technomyrmex albipes & 19 & 0.9 & 33.3 & 0 & Yes \\
\hline \multirow[t]{7}{*}{ Ponerinae } & Brachyponera chinensis & 64 & 4.3 & 58.3 & TCS & No \\
\hline & Diacamma rugosum & 174 & 13.3 & 75 & 0 & No \\
\hline & Leptogenys peuqueti & 261 & 2.2 & 66.7 & SP & No \\
\hline & Leptogenys sp. & 28 & 0.2 & 8.3 & SP & No \\
\hline & Odontomachus simillimus & 1 & 0.5 & 16.7 & 0 & No \\
\hline & Odontoponera denticulata & 8 & 19.6 & 83.3 & SP & No \\
\hline & Platythyrea paralella & 300 & 0.4 & 8.3 & SP & No \\
\hline
\end{tabular}

Abbreviations: (DD) Dominant Dolichoderinae; (SC) Subordinate Camponotini, (TCS) Tropical-climate Specialists; (HCS) Hot-climate Specialists; (0) Opportunists; (GM) Generalised Myrmicinae; (SP) Specialist Predators; (C) Cryptic species; *Status for invasive species by The Global Invasive Species Database (GISD, 2020).

Information on ant functional groups and invasive status are presented in Tables 2 and 3. Eight functional groups of ants were identified; the most abundant were Opportunists (0) and Tropical-Climate Specialists (TCS). Only one species of Hot-Climate Specialists (HCS) was identified in this study. Invasive ants (a total of seven species), including Anoplolepis gracilipes and Monomorium floricola, were collected from all parks, albeit at different frequencies and species numbers. 
Details of each subfamily recorded in this study are presented in Table 4. The highest number of species and individuals were from the Myrmicinae and Formicinae, while only a single species was recorded for the Ectatomminae.

Table 4

Total species and individual of ants from six subfamilies collected from 12 urban parks inside the Federal Territory of Kuala Lumpur, Malaysia.

\begin{tabular}{|lllll|}
\hline \multirow{2}{*}{ Subfamily } & \multicolumn{2}{l}{ Species } & \multicolumn{2}{l|}{ Individual } \\
\cline { 2 - 5 } & Total & Proportional (\%) & Total & Proportional (\%) \\
\hline Dolichocerinae & 6 & 12.2 & 1060 & 11.0 \\
\hline Ectatomminae & 1 & 2.0 & 2 & 0.02 \\
\hline Formicinae & 11 & 22.4 & 3990 & 41.2 \\
\hline Myrmicinae & 21 & 43.0 & 3784 & 39.1 \\
\hline Ponerinae & 7 & 14.3 & 773 & 8.0 \\
\hline Pseudomyrmecinae & 3 & 6.1 & 68 & 0.7 \\
\hline TOTAL & 49 & 100 & 9,677 & 100 \\
\hline
\end{tabular}

Species richness and estimated richness are shown in Table 5. The overall estimated species richness was between 52 and 60 species, with more than $81 \%$ sampling efficiency. The estimated species richness for each urban park ranged from 17 to 31 species, indicating more than $80 \%$ sampling efficiency. The species accumulation curve showed that the sample size of ants was sufficient to accurately describe ant species diversity, since a plateau was reached after approximately 80 samplings (Fig. 2). 
Table 5

Species count, mean and standard error of ants species abundance and sampling efficiency* values (percentages given in brackets) of different species estimators for different parks. Highest and lowest estimates of sampling efficiency for each estimator are stated in bold.

\begin{tabular}{|c|c|c|c|c|c|c|}
\hline Parks & $\begin{array}{l}\text { Species } \\
\text { count }\end{array}$ & $\begin{array}{l}\text { Mean abundance } \\
( \pm \text { SE) }\end{array}$ & Chao1 & Jack1 & Jack2 & Bootstrap \\
\hline \multirow[t]{2}{*}{ Overall } & 49 & 197.48 & 57.14 & 55.97 & 59.96 & 52.02 \\
\hline & & \pm 48.84 & (85.75) & (87.55) & (81.72) & (94.19) \\
\hline \multirow[t]{2}{*}{ TAD } & 22 & 21.68 & 24.24 & 24.99 & 25.99 & 23.58 \\
\hline & & \pm 9.46 & $(90.75)$ & (88.04) & (84.65) & (93.31) \\
\hline \multirow[t]{2}{*}{ TAH } & 19 & 41.00 & 19.25 & 20.00 & 19.01 & 19.80 \\
\hline & & \pm 18.34 & (98.71) & $(95.02)$ & (99.94) & (95.96) \\
\hline \multirow[t]{2}{*}{ TAK } & 18 & 36.56 & 19.49 & 20.99 & 21.00 & 19.60 \\
\hline & & \pm 12.68 & (92.33) & (85.76) & (85.71) & (91.81) \\
\hline \multirow[t]{2}{*}{ TBJ } & 24 & 27.33 & 30.23 & 28.98 & 31.97 & 26.21 \\
\hline & & \pm 9.15 & $(79.40)$ & $(82.81)$ & (75.08) & (91.58) \\
\hline \multirow[t]{2}{*}{ TBP } & 25 & 38.33 & 27.66 & 28.99 & 29.99 & 27.01 \\
\hline & & \pm 15.59 & (90.39) & (86.25) & (83.36) & (92.56) \\
\hline \multirow[t]{2}{*}{ TDB } & 25 & 59.12 & 27.24 & 27.99 & 28.99 & 26.48 \\
\hline & & \pm 20.91 & (91.77) & (89.32) & (86.24) & (94.42) \\
\hline \multirow[t]{2}{*}{ TDK } & 17 & 51.24 & 17.50 & 18.00 & 18.00 & 17.54 \\
\hline & & \pm 14.92 & (97.15) & $(94.46)$ & (94.44) & (96.94) \\
\hline \multirow[t]{2}{*}{ TMB } & 20 & 33.65 & 21.99 & 21.99 & 22.99 & 21.02 \\
\hline & & \pm 10.70 & $(90.94)$ & (90.94) & (87.00) & (95.14) \\
\hline \multirow[t]{2}{*}{ TMK } & 26 & 20.77 & 30.48 & 28.99 & 30.98 & 27.38 \\
\hline & & \pm 4.78 & (85.29) & (89.69) & (83.93) & (94.97) \\
\hline \multirow[t]{2}{*}{ TPU } & 17 & 43.76 & 17.25 & 18.00 & 17.01 & 17.79 \\
\hline & & \pm 24.61 & $(98.56)$ & $(94.46)$ & (99.93) & (95.53) \\
\hline \multirow[t]{2}{*}{ TTM } & 22 & 39.14 & 26.48 & 24.99 & 26.98 & 23.38 \\
\hline & & \pm 11.76 & & & & \\
\hline
\end{tabular}




\begin{tabular}{|lllllll|}
\hline Parks & $\begin{array}{l}\text { Species } \\
\text { count }\end{array}$ & $\begin{array}{l}\text { Mean abundance } \\
( \pm \text { SE) }\end{array}$ & Chao1 & Jack1 & Jack2 & Bootstrap \\
\hline TTP & 23 & 37.74 & $(83.07)$ & $(88.04)$ & $(81.55)$ & $(94.11)$ \\
& \pm 12.33 & 27.48 & 25.99 & 27.98 & 24.43 \\
\cline { 2 - 6 } & $(83.69)$ & $(88.50)$ & $(82.21)$ & $(94.16)$ \\
\hline $\begin{array}{l}\text { *Sampling efficiency was calculated by dividing the actual species collected by the number of } \\
\text { estimated species (Ya'cob et al., 2016). }\end{array}$ \\
\hline
\end{tabular}

\section{Ant diversity}

The diversity indices for the parks are shown in Table 6. Ant diversity did not differ significantly between the 12 urban parks inside Kuala Lumpur $(H=7.84, \mathrm{df}=11, p>0.05)$. However, the diversity index was highest at TMK (2.76) followed by TBJ (2.39), TTM (2.34), and TDK (2.29). The least diverse ant community was at TPU (1.62). The similarity in species diversity is shown in Fig. 3. Ant species were $70 \%$ similar between TTP and TMB, followed by $60 \%$ similarity between TAD and TPU. In addition, functional groups $(H=5.8, \mathrm{df}=11, p=0.88)$ and invasive species $(H=2.76, \mathrm{df}=11, p=0.99)$ did not differ between parks. 
Table 6

Diversity indices for ant community at 12 parks inside the Kuala Lumpur. The highest and lowest values for each index are stated in bold.

\begin{tabular}{|c|c|c|c|c|}
\hline \multirow[t]{2}{*}{ Parks } & \multicolumn{3}{|c|}{ Diversity indices } & \multirow{2}{*}{$\begin{array}{l}\text { W } \\
\text { (p-value) }\end{array}$} \\
\hline & $H^{\prime}$ & D & $\mathbf{J}$ & \\
\hline TAD & 2.09 & 0.77 & 0.68 & $P<0.05$ \\
\hline TAH & 1.89 & 0.76 & 0.64 & $P<0.05$ \\
\hline TAK & 2.08 & 0.83 & 0.72 & $P<0.05$ \\
\hline TBJ & 2.39 & 0.85 & 0.75 & $P<0.05$ \\
\hline TBP & 2.14 & 0.80 & 0.67 & $P<0.05$ \\
\hline TDB & 2.27 & 0.83 & 0.70 & $P<0.05$ \\
\hline TDK & 2.29 & 0.87 & 0.81 & $P<0.05$ \\
\hline TMB & 2.18 & 0.82 & 0.73 & $P<0.05$ \\
\hline TMK & 2.76 & 0.91 & 0.85 & $P<0.05$ \\
\hline TPU & 1.62 & 0.65 & 0.57 & $P<0.05$ \\
\hline TTP & 2.27 & 0.85 & 0.72 & $P<0.05$ \\
\hline TTM & 2.34 & 0.87 & 0.76 & $P<0.05$ \\
\hline
\end{tabular}

Species rank abundance is shown in Fig. 4. The total number of species collected at each park ranged between 17 to 26 with an average of $21.5 \pm 3.1$. Ant species abundance was highest in TMK (mean \pm SE: $20.8 \pm 4.8)$ followed TBP $(38.3 \pm 15.6)$ and TDB $(59.1 \pm 20.9)$. Species was lowest at TPU $(43.8 \pm 24.6)$ and TDK (51.2 \pm 14.9$)$ (Table 5). Oecophylla smaragdina was the dominant species in seven parks with the number of individuals ranging from 188 to 418 with a mean (SE) of $249 \pm 30.1$. However, this species was not collected at TBP and TDK. Other species, Tetramorium smithi, Dolichoderus thoracicus, Carebara diversa, Monomorium orientale, and Anoplolepis gracilipes, were dominant at TAH, TBP, TDB, TDK, and TMK, respectively (Fig. 4).

\section{Discussion}

Ants are used as indicators to assess landscape conversion due to their rapid response to changes in climate/environmental parameters (Cuautle et al., 2016). Urban parks are some of the most highly disturbed areas within ecosystems, and their flora and fauna are expected to be less diverse than those of natural forests. This assumption is based on many factors, the most important being habitat complexity. Urban habitats are less complex because of lower diversity of ecological structure compared to natural 
forests that offer greater habitat heterogeneity, which allows a wider variety of habitat choices for most ant species (Cuautle et al., 2016).

This study provides the first checklist of ant species for Kuala Lumpur's urban parks. The urban parks in this study showed no significant differences in ant diversity and composition. This is probably due to all parks sharing similar ecological characteristics, such as the composition of common tree species and climate. This may also reflect the local councils' excellent parks management and maintenance. Several forest-affiliated ant taxa, such as Gnamptogenys sp., Platythyrea parallela, Proatta butteli, and Strumigenys sp., were collected from the parks suggesting that their ecosystem status has improved to the point of preserving biodiversity. These forest-associated species are commonly found in rotten wood and leaf litter in tropical and subtropical mesic forests. Platythyrea parallela is common in logs, tree trunks, and rotten wood, and is deemed to be rare since observations of stable colony nests are few (Ashikin \& Hashim, 2015). Proatta butteli is found in leaf litter and rotten logs in tropical rainforests and is important to the ecosystem as it recycles nutrients back into soil (Moffett, 1986). Strumigenys tends to associate with primary and secondary rainforest, but several species within this genus, i.e., S. emmae and S. membranifera, are tramp species found in open disturbed habitats (Tang et al., 2019). Another notable observation of this study is the presence of Dolichoderus thoracicus rufescens in Taman Dusun Bandar (TDB), which has been described to date only in Sarawak, East Malaysia. Our observation is the first record for Peninsular Malaysia. Although the biology of this subspecies is unknown (Dill, 2002), the presence of this subspecies is most possibly due to the presence of various tropical fruiting trees which dominates the vegetation in this park.

The species accumulation curve reached an asymptote, which indicates that the sampling method applied in this study was effective enough to successfully sample most of the species present. Further sampling of ants and ant-associated environmental parameters at different times is vital to reveal the distributional patterns and ecology of metropolitan species.

Oecophylla smaragdina was the most common species found in this study, occurring in 10 parks, and dominating in seven. This species is well known for its predatory, aggressive, and territorial behavior, which potentially deters other species, resulting in low species diversity and evenness in sites where it occurs (Fig. 5). However, periodical surveillance of this predatory species is necessary to ensure urban biodiversity is in consistent balance. The success of this dominant species is due to its large body size, enormous colonies, extensive foraging range, and the ability to construct nests nearly everywhere from leaves of almost any shape (Bharti \& Silla, 2011; Holldobler, 1983; Van Mele \& Cuc, 2000). Despite being regarded as a threat, $O$. smaragdina also provides valuable benefits for the urban park ecosystem as a biological control agent. Its aggressiveness and predatory habit help in the control of heteropteran, lepidopteran, and leaf-feeding coleopteran pests (Van Mele, 2008). Their wastes may provide useful nutrients for plants, which in turn aids in the nutrient cycle (Barzman et al., 1996).

Based on the Global Invasive Species Database (GISD) of the International Union for Conservation of Nature (IUCN) and Antkey.org, seven (14.3\%) of the 49 species recorded in this study were categorized as 
invasive in this region. The presence of these invasive species was corroborated by a previous study of urban ants in the state of Penang, which demonstrates that they are common inhabitants of highly urbanized areas (Ab-Majid et al., 2016; Na \& Lee, 2001). Invasive ants were found in all the parks sampled, regardless of the total number of ant species present. In fact, a few of the invasive species were among the most abundant and dominant in certain parks (Fig. 4). Their presence may be influenced by other factors, for example, anthropogenic activities, since the urban parks are close to human habitation. However, the actual roles and functions of these invasive ants remain undetermined. Previous studies suggest that the introduction of invasive ants is disruptive to native species abundance and diversity (Dejean et al., 2007; Fournier et al., 2012; Strayer, 2012). Despite their invasive behaviors, this study showed that the percentage abundance of this group was positively correlated with species evenness (Fig. 6), indicating stabilized biodiversity. Therefore, they seem to have little impact on the ecosystem compared to "high-impact" invaders, which alter ecosystem functions (Strayer, 2012). Consequently, periodic surveillance of urban ants is necessary to ensure that biodiversity equilibrium persists in line with urban conservation strategy.

Our study found eight out of the nine ant functional groups proposed by Andersen (2000). Undoubtedly, Opportunists $(0)$ are the most abundant group due to having a wide range of ecological preferences, high tolerance to harsh and highly modified environments, less sensitivity to small changes in edaphic factors, poor competitive behavior, and very large habitat distributions (Grime, 1979; Masse et al., 2021). In contrast, the highly thermophilic Hot-Climate Specialists (HCS) are exclusive to arid and semi-arid environments, strongly prefer open habitats, and consequently, are regarded as a rare group (Gosper et al., 2015). The low abundance of Dominant Dolichoderinae (DD) and Hot-Climate Specialists (HCS) was predicted because both functional groups are affected by the presence of Tropical-Climate Specialists (TCS) and Generalized Myrmicinae (GM). High abundance of Tropical-Climate Specialists (TCS) is a characteristic of habitats where the abundance of Dominant Dolichoderinae (DD) is low (Andersen, 2000), thus resulting in low numbers of these two functional groups within the community. Low Dominant Dolichoderinae (DD) density, in turn, reduces the abundance of Hot-Climate Specialists (HCS) present in a particular habitat. Generalized Myrmicinae (GM) were ranked the third most abundant functional group in this study; they are often in competitive tension with Dominant Dolichoderinae (DD), including in tropical rainforests (Andersen, 2000). Apart from Hot-Climate Specialists (HCS) and Dominant Dolichoderinae (DD), Cryptic (C), Subordinate Camponotini (SC), and Specialist Predators (SP) ranked relatively low in abundance in this study. Cryptic (C) and Subordinate Camponotini (SC) are normally most diverse and abundant in forest habitats and rich ant communities, whereas Specialist Predators (SP) rarely interact with other ants due to their low population densities (Andersen, 2000).

\section{Conclusion}

Research on urban tropical habitats is crucial as it can increase the knowledge of ant species occurrence, allowing better assessment of the biodiversity and conservation potential of semi-natural habitats. This first checklist of ants for highly urbanized areas in Peninsular Malaysia will become a foundational framework for future studies. We hope that data will be collected continuously to further improve the 
checklist and provide concrete information on the ecological relationships between invasive and native ant species. Our results demonstrate the importance of tramp species in shaping the myrmecofauna of tropical urban habitats. The fact that not all parks were dominated by invasive species suggests that other factors, such as environmental parameters and the vegetation mosaic, underlie the occurrence of these species. This highlights the importance and scientific challenge of follow-up studies on ant assemblages and species interactions in urban tropical ecosystems, as part of a yet underdeveloped line of ecological research (Whitten et al. 1996). Comparisons with other myrmecological studies in tropical urban habitats are yet to be carried out due to the general lack of biodiversity inventories for urbanized habitats in Malaysia. Moreover, the ecosystem dynamics of a few notable ant species, such as $A$. gracilipes, $D$. thoracicus, $O$. smaragdina and their interactions with other fauna of urban ecosystems are worthy of future study in order to enhance our understanding of urban ecology.

\section{Declarations}

\section{ACKNOWLEDGEMENT}

This study was funded by Universiti Malaya's Faculty Research Grant GPF010B-2018. We thank Kuala Lumpur City Hall (DBKL) for giving us permission to conduct our study. We would also like to extend our gratitude to our colleagues for their valuable help. Special thanks to Prof. Seiki Yamane (Kagoshima University, Japan), Dr. Weeyawat Jaitrong (National Science Museum, Thailand), Mr. Zakaria Barabag (Universiti Malaysia Sabah, Malaysia), Ms. Nurfarahin Mustafa and Ms. Nur Sakinah Mohd Yassin (Universiti Malaya, Malaysia) for their help in confirming identifications; and Ms. Nur Zati Akma Mustafa (Forest Research Institute Malaysia) for help with FRIM collections and references.

\section{Funding}

This work was supported by the Universiti Malaya's Faculty Research Grant GPF010B-2018 through the Institute of Research Management and Services (IPPP), Universiti Malaya.

\section{Conflict of Interest/Competing interests}

The authors have no conflicts to declare.

\section{Availability of data and material}

Material is available at Universiti Malaya's Museum of Zoology (MZUM), Faculty of Science, Universiti Malaya.

\section{Code availability}

Not applicable.

\section{Authors' contributions}


AAM lead the sampling, determined species identification, made statistical analysis and wrote the first draft of the manuscript. NAA, ZY and MSM critically and substantially commented and edited all version of the manuscript drafts. All authors read and approved the final manuscript.

\section{Ethics approval}

Not applicable.

\section{Consent to participate}

Not applicable.

\section{Consent for publication}

Not applicable.

\section{References}

1. Ab-Majid AH, Ellias SS, Ahmad H, Hassan A, Ahmad HD (2016) Tropical household ants species composition and distribution in rapid urbanization area in Penang, Malaysia. Journal of Entomology Zoology Studies 4:496-500

2. Abdullah NA, Hashim R (2010) An Inventory of Ants (Hymenoptera: Formicidae) at Melawi Sandy Beach, Bachok, Kelantan. Malaysian Journal of Science, 29 (Special Issue), 67-72. doi:https://doi.org/10.22452/mjs.vol29nosp.7

3. Akbar SA, Bharti H (2017) A New Species of the Ant Genus Carebara Westwood (Hymenoptera: Formicidae) from India. Journal of the Entomological Research Society 19(3):35-43

4. Andersen AN (1999) My bioindicator or yours? Making the selection. J Insect Conserv 3:61-64

5. Andersen AN (2000) A global ecology of rainforest ants: Functional groups in relation to environmental stress and disturbance. In: Agosti D, Majer J, Alonso L, Schultz T (eds) Ants: Standard Methods for Measuring and Monitoring Biodiversity. Smithsonian Institution Press, Washington D. C., pp 25-34

6. Andersen AN, Hoffmann BD, Somes J (2003) Ants as indicators of minesite restoration: community recovery at one of eight rehabilitation sites in central Queensland. Ecological Management Restoration 4:S12-S19. doi:https://doi.org/10.1046/j.1442-8903.4.s.2

7. Andersen AN, Mayer JD (2004) Ants show the way Down Under: invertebrates as bioindicators in land management. Front Ecol Environ 2(6):291-298. doi:https://doi.org/10.1890/15409295(2004)002[0292:ASTWDU]2.0.C0;2

8. Andersson E, McPhearson T, Kremer P, Gomez-Baggethun E, Haase D, Tuvendal M, Wurster D (2015) Scale and context dependence of ecosystem service providing units. Ecosystem Services 12:157164. doi:10.1016/j.ecoser.2014.08.001 
9. Ashikin N, Hashim R (2015) Daily activity patterns of Platythyrea parallela in Peninsular Malaysia. Asian Myrmecology 7:145-154. doi:10.20362/am.007015

10. Barzman MS, Mills NJ, Thu Cuc NT (1996) Traditional Knowledge and Rationale for Weaver Ant Husbandry in the Mekong Delta of Vietnam. 13(4), 2-9. doi:doi:10.1007/bf01530519

11. Bharti H, Silla S (2011) Notes on life history of Oecophylla smaragdina and its potential as biological control agent. Halteres 3:57-64

12. Bharti H, Wachkoo AA (2013) Two new species of the ant genus Leptogenys (Hymenoptera: Formicidae) from India, with description of a plesiomorphic ergatogyne. Asian Myrmecology 5:1119

13. Brown KSJ (1997) Diversity, disturbance, and sustainable use of Neotropical forests: Insects as indicators for conservation monitoring. J Insect Conserv 1:25-42. doi:10.1023/A:1018422807610

14. Cuautle M, Vergara CH, Badano El (2016) Comparison of Ant Community Diversity and Functional Group Composition Associated to Land Use Change in a Seasonally Dry Oak Forest. Neotropical Entomology 45:170-179. doi:https://doi.org/10.1007/s13744-015-0353-y

15. Dejean A, Moreau CS, Uzac P, Le Breton J, Kenne M (2007) The predatory behavior of Pheidole megacephala. CR Biol 330(9):701-709. doi:10.1016/j.crvi.2007.06.005

16. Dill M (2002) Taxonomy of the migrating herdsmen species of the genus Dolichoderus Lund, 1831, with remarks on the systematics of other southeast-Asian Dolichoderus. In: Dill M, Williams DJ, Maschwitz $\mathrm{U}$ (eds) Herdsmen ants and their mealybug partners (Vol, 557. Abhandlungen der Senckenbergischen Naturforschenden Gesellschaft, pp 17-113

17. Eguchi K (2001) A Revision of the Bornean Species of the Ant Genus Pheidole (Insecta: Hymenoptera: Formicidae: Myrmicinae). Tropics MonographNo 2(0):1-154. doi:10.3759/tropics.monographno.2_1

18. Fattorini S (2016) Insects and the city: what island biogeography tells us about insect conservation in urban areas. Web Ecol 16(1):41-45. doi:10.5194/we-16-41-2016

19. Fayle TM, Yusah KM, Hashimoto Y (2014) Key to the ant genera of Borneo in English and Malay

20. Folgarait PJ (1998) Ant biodiversity and its relationship to ecosystem functioning: a review. Biodivers Conserv 7(9):1221-1244. doi:10.1023/a:1008891901953

21. Fournier D, Tindo M, Kenne M, Masse M, Van Bossche PS, De Coninck V, E., \& Aron S (2012) Genetic Structure, Nestmate Recognition and Behaviour of Two Cryptic Species of the Invasive Big-Headed Ant Pheidole megacephala. PLoS ONE 7(2):e31480. doi:10.1371/journal.pone.0031480

22. Grime JP (1979) Plant strategies, vegetation processes, and ecosystem properties. John Wiley \& Sons, Chichester

23. Grootaert P, Pollet M, Dekoninck W, van Achterberg C (2010) Sampling insects: general techniques, strategies and remarks. In: Eymann J, Degreef J, Hāuser J, Monje C, Samyn Y, Vanden Spiegel D (eds) Manual on Field Recording Techniques and Protocols for All Taxa Biodiversity Inventories and Monitoring. Abc Taxa, Belgium, pp 337-399 
24. Heterick BE, Shattuck S (2011) Revision of the ant genus Iridomyrmex (Hymenoptera: Formicidae). Zootaxa 2845:1-174. doi:https://doi.org/10.11646/zootaxa.2845.1.1

25. Holldobler B (1983) Territorial behavior in the green tree ant (Oecophylla smaragdina). Biotropica 15(4):241-250. doi:https://doi.org/10.2307/2387648

26. Karmaly KA (2004) A new species and a key to species of Polyrhachis Smith (Hymenoptera: Formicidae) from India. In: Rajmohana K, Sudheer K, Girish Kumar P, Santhosh S (eds) Perspectives on biosystematics and biodiversity. Prof. T.C. Narendran commemoration volume (Vol, 22. Systematic Entomology Research Scholars Association, Kerala, pp 539-551

27. Koch F, Vohland K (2008) Ants along a southern African transect-a basis for biodiversity change monitoring (Insecta, Hymenoptera, Formicidae). Zoosystematics Evolution 80:261-273. doi:https://doi.org/10.1002/mmnz.20040800206

28. Kremen $C$ (1992) Assessing the indicator properties of species assemblages for natural areas monitoring. Ecol Appl 2:203-217. doi:10.2307/1941776

29. Lawes MJ, Kotze DJ, Bourquin SL, Morris C (2005) Epigaeic invertebrates as potential ecological indicators of Afromontane forest condition in South Africa. Biotropica 37:109-118. doi:https://doi.org/10.1111/j.1744-7429.2005.04054.x

30. Malsch AKF, Rosciszewski K, Maschwitz U (2003) The Ant Species Richness and Diversity of a Primary Lowland Rain Forest, the Pasoh Forest Reserve, West-Malaysia. In: \& A. P.S. (Eds.), Pasoh. Springer, Tokyo M. N, M. Y, N. K, T. S.C., ). In O. T,

31. Marshall E, Shortle JS (2005) Urban development impacts on ecosystems. In: Goetz SJ, Shortle JS, Bergstrom JC (eds) Land use problems and conflicts: causes, consequences and solutions. Routledge, London, pp 79-93

32. Masse PSM, Ebolo GM, Titti GE, Mony R (2021) Ant species richness, abundance and functional groups along an elevational gradient in Central Cameroon. Biodiversity Journal 12(1):179-194. doi:https://doi.org/10.31396/Biodiv.Jour.2021.12.1.179.194

33. McGeoch MA (1998) The selection, testing and application of terrestrial insects as bioindicators. Biol Rev 73:181-201. doi:https://doi.org/10.1111/j.1469-185X.1997.tb00029.x

34. McIntyre NE (2000) Ecology of urban arthropods: a review and a call to action. Ann Entomol Soc Am 93(4):825-835. doi:https://doi.org/10.1603/0013-8746(2000)093[0825:EOUAAR]2.0.C0;2

35. Moffett MW (1986) Observations of Lophomyrmex ants from Kalimantan, Java and Malaysia. Malayan Nature Journal 39:207-211. doi:http://doi.org/10.5281/zenodo.25804

36. Mustafa N-ZA, Salim HM, Fletcher C, Kassim AR, Potts MD (2011) Taxonomic and functional diversity of ants (Hymenoptera: Formicidae) in an upper hill dipterocarp forest in Peninsular Malaysia. Raffles Bulletin of Zoology 59(2):181-194

37. Na JP, Lee CY (2001) Identification key to common urban pest ants in Malaysia. Trop Biomed 18(1):1-17

38. Noor-Izwan A, Amirrudin BA (2014) Diversity of ants (Hymenoptera: Formicidae) at Kuala Lompat, Krau Wildlife Reserve, Pahang, Malaysia. Journal of Wildlife Parks 28:31-39 
39. Norasmah B, Abu-Hassan A, Che-Salmah MR, Nurita AT, Nuraida H (2006) Species composition, monthly abundance and food preferences of structure-infesting ants (Hymenoptera: Formicidae) in student housing in USM, Penang, Malaysia. Malaysian Applied Biology 35(2):1-12

40. O'Neill A (2021) Urbanization in Malaysia 2019. Retrieved 19th June 2021, from Statista

41. Pfeiffer M, Mezger D, Hosoishi S, Bakhtiar EY, Kohout RJ (2011) The Formicidae of Borneo (Insecta: Hymenoptera): a preliminary species list. Asian Myrmecology 4(1):9-58

42. Santos MN (2016) Research on urban ants: approaches and gaps. Insectes Sociaux 63(3):359-371

43. Strayer DL (2012) Eight questions about invasions and ecosystem functioning. Ecol Lett 15(10):1199-1210. doi:10.1111/j.1461-0248.2012.01817.x

44. Tang KL, Pierce MP, Guénard B (2019) Review of the genus Strumigenys (Hymenoptera, Formicidae, Myrmicinae) in Hong Kong with the description of three new species and the addition of five native and four introduced species records. ZooKeys 831:1-48. doi:10.3897/zookeys.831.31515

45. Uehara-Prado M, Fernandes JDO, Bello ADM, Machado G, Santos AJ, Vaz-de-Mello FZ, Freitas AVL (2009) Selecting terrestrial arthropods as indicators of small-scale disturbance: A first approach in the Brazilian Atlantic Forest. Biol Cons 142:1220-1228. doi:10.1016/j.biocon.2009.01.008

46. Underwood EC, Fisher BL (2006) The role of ants in conservation monitoring: if, when, and how. Biol Cons 132:166-182. doi:https://doi.org/10.1016/j.biocon.2006.03.022

47. Van Mele P (2008) A historical review of research on the weaver ant Oecophylla in biological control. Agric For Entomol 0(0):071101073646001. doi:10.1111/j.1461-9563.2007.00350.x

48. Van Mele P, Cuc NTT (2000) Evolution and status of Oecophylla smaragdina (Fabricius) as a pest control agent in citrus in the Mekong Delta, Vietnam. International Journal of Pest Management 46(4):295-301. doi:https://doi.org/10.1080/09670870050206073

49. Ya'cob Z, Takaoka H, Pramual P, Low VL, Sofian-Azirun M (2016) Distribution pattern of black fly (Diptera: Simuliidae) assemblages along an altitudinal gradient in Peninsular Malaysia. Parasites Vectors, 9(1). doi:10.1186/s13071-016-1492-7

50. Yaakob U, Masron T, Masami F (2010) Ninety years of urbanization in Malaysia: a geographical investigation of its trends and characteristics. Journal of Ritsumeikan Social Sciences Humanities 4(3):79-101

51. Yap HH, Lee CY (1994) A preliminary study on the species composition of household ants on Penang Island, Malaysia. Journal of Bioscience 5:64-66

52. Ye S, Fang Y, Li K (2013) Impacts of urbanization process on insect diversity. Biodiversity Science 21(3):260-268. doi:10.3724/sp.j.1003.2013.09206

\section{Figures}




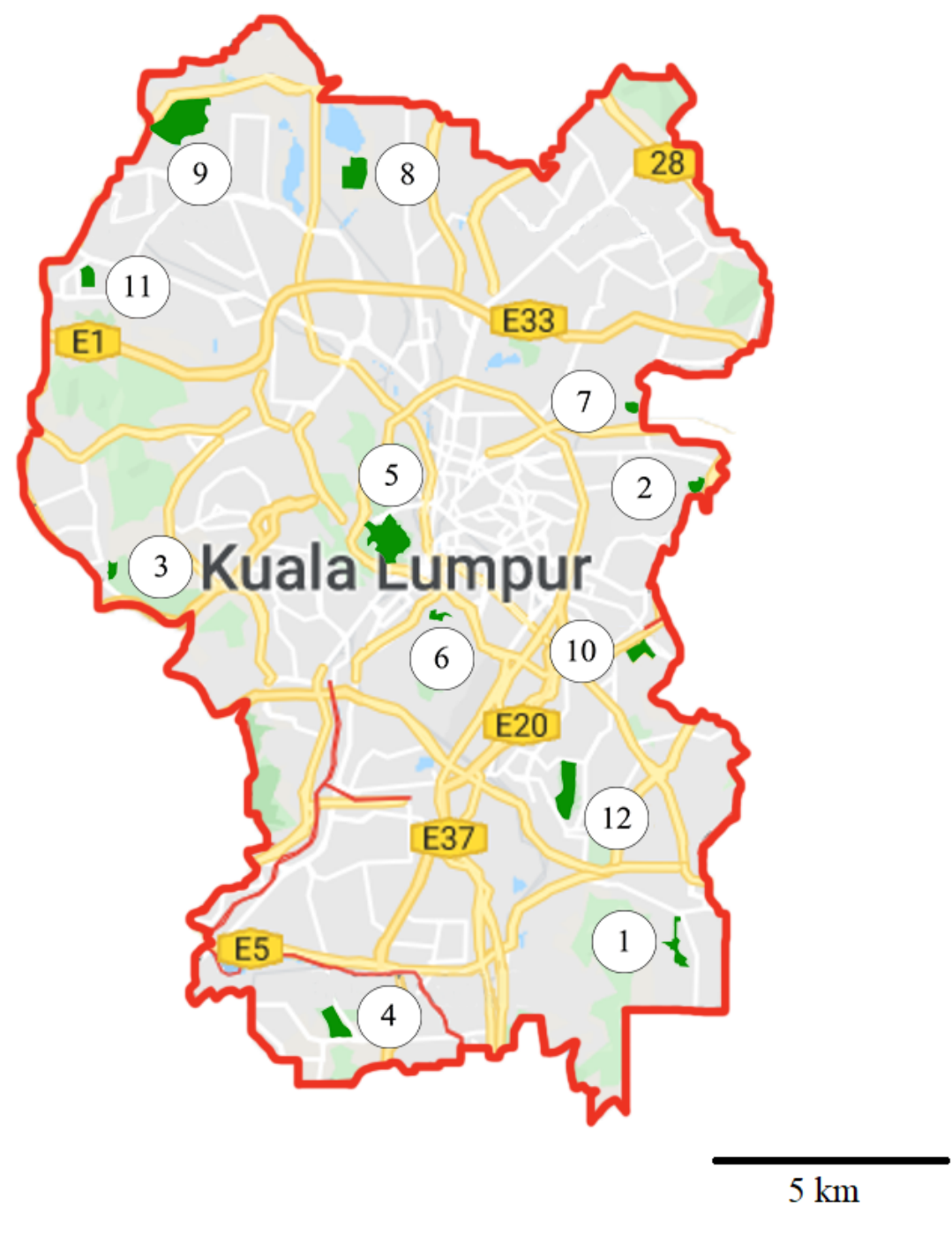

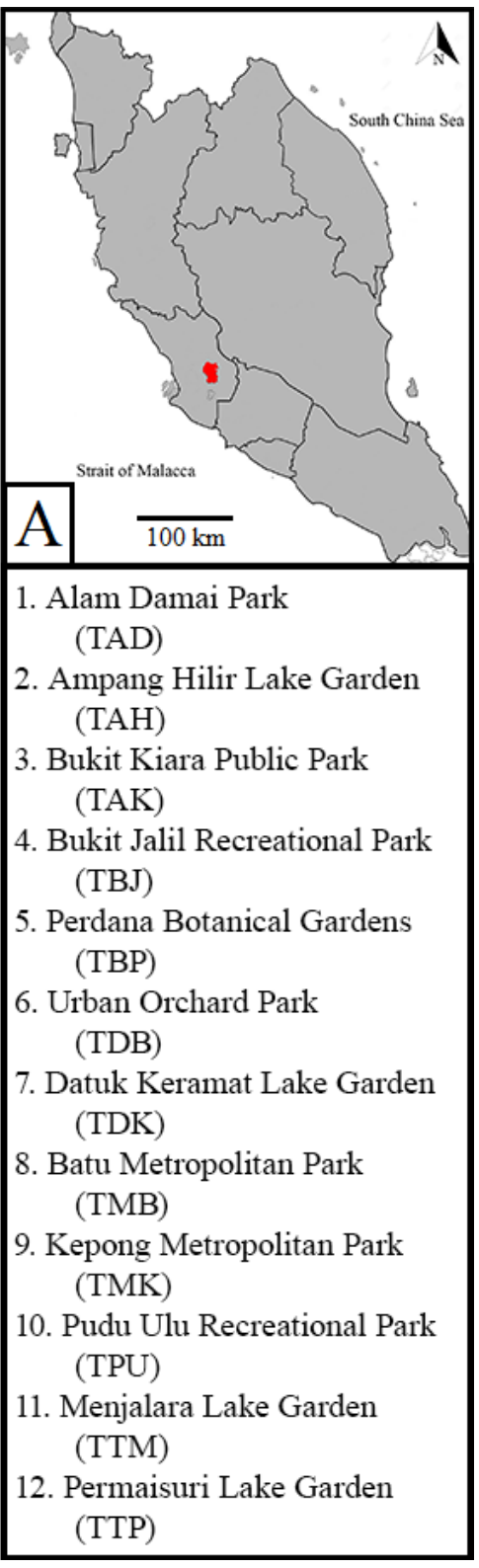

Figure 1

The map showing: (A) the map of Peninsular Malaysia with Kuala Lumpur highlighted in red, and (B) the locations of Kuala Lumpur urban parks (highlighted green) where the surveys were conducted (modified after Google Map 2020) 


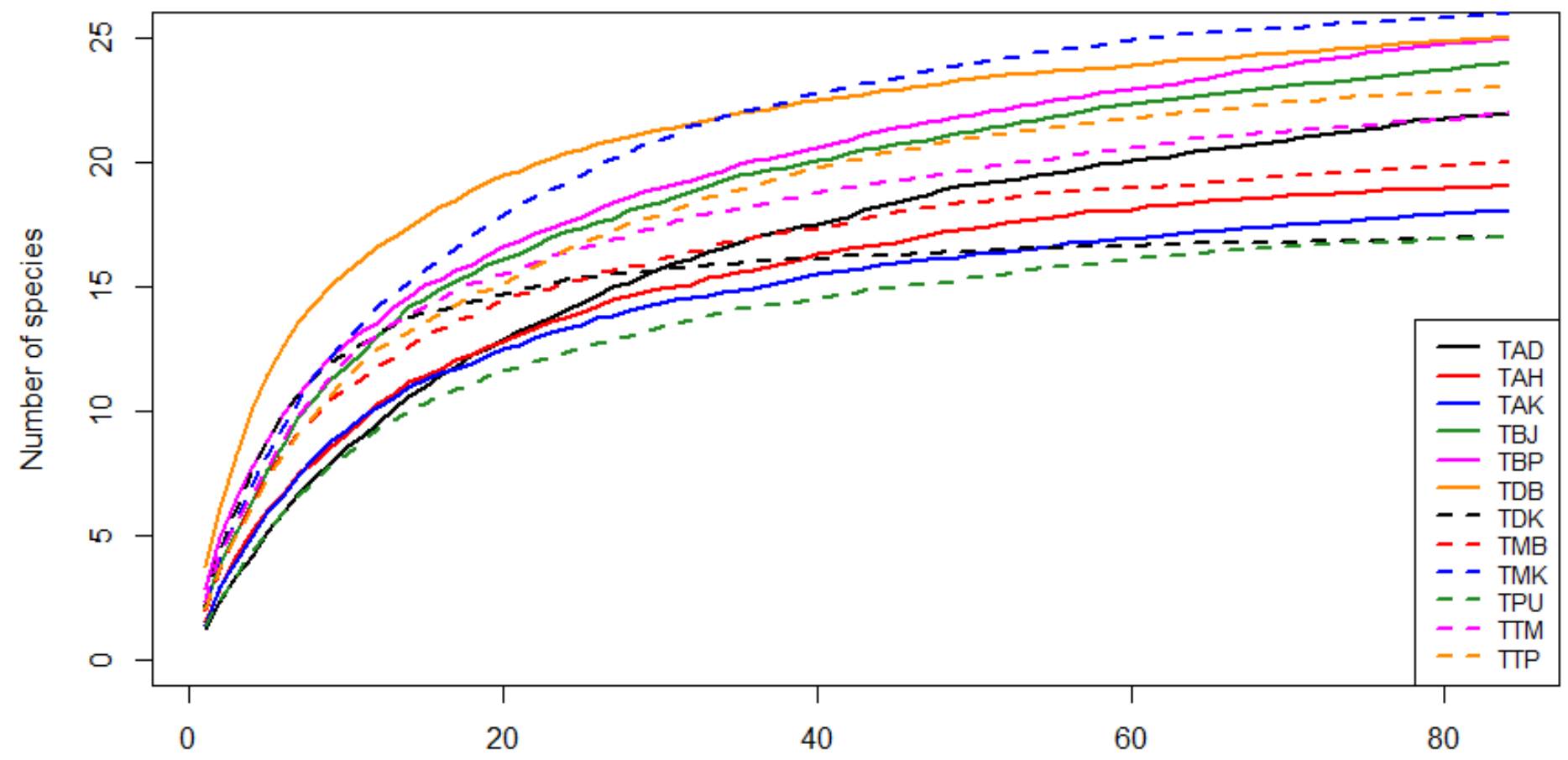

Number of traps

Figure 2

Species accumulation curves (randomized 100 runs) of the different parks 


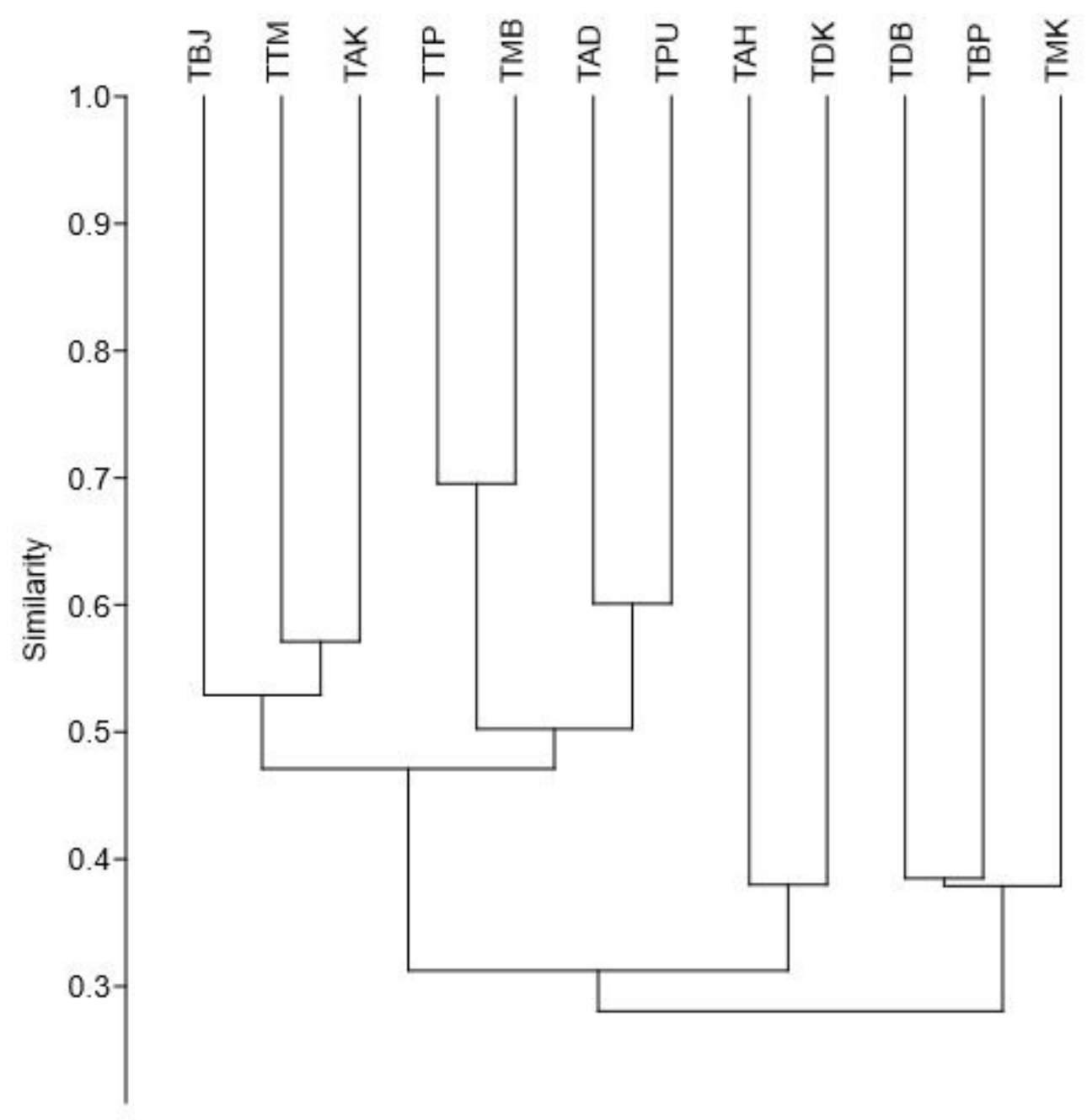

Figure 3

Cluster analysis based on Bray-Curtis species similarity index between 12 urban parks inside the Federal Territory of Kuala Lumpur 
TAD

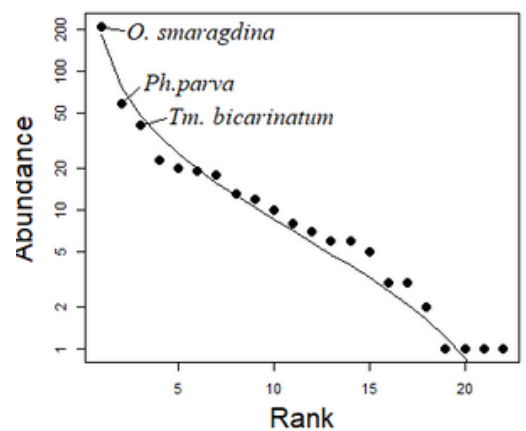

TBJ

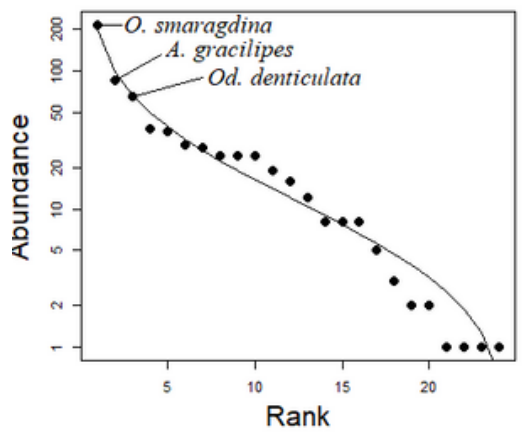

TDK

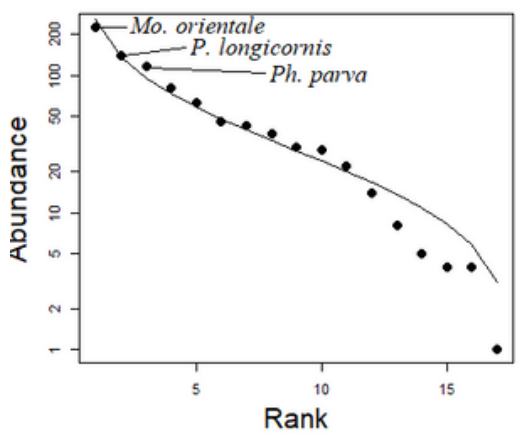

TPU

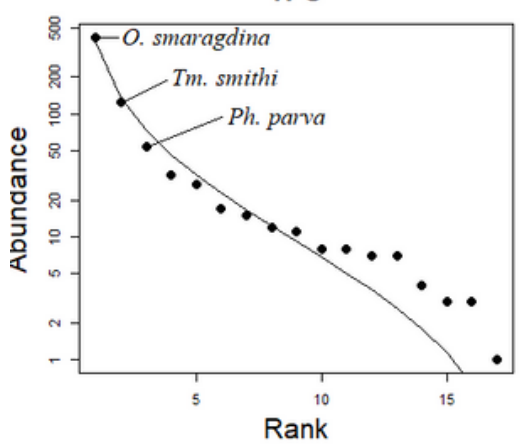

TAH

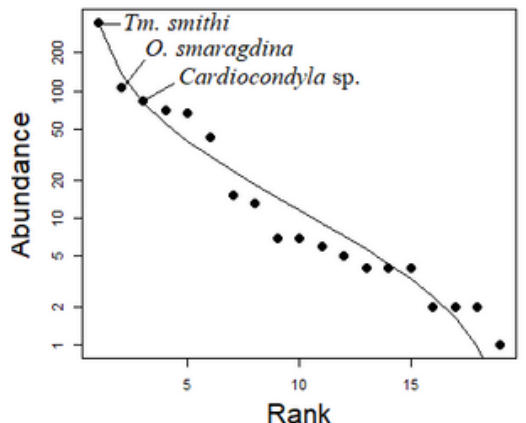

TBP

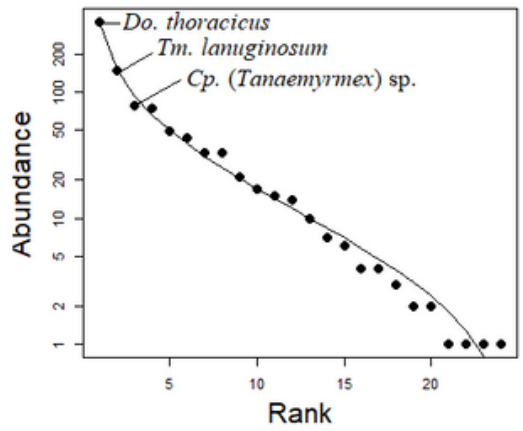

TMB

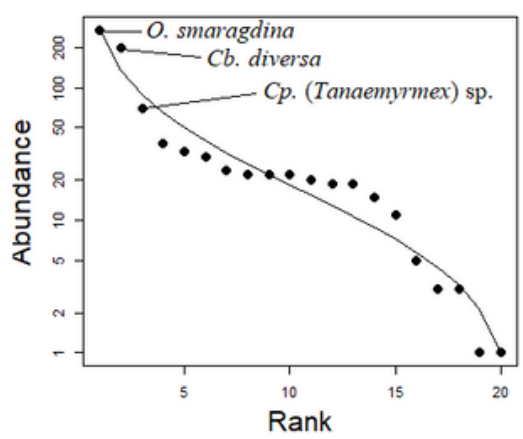

TTM

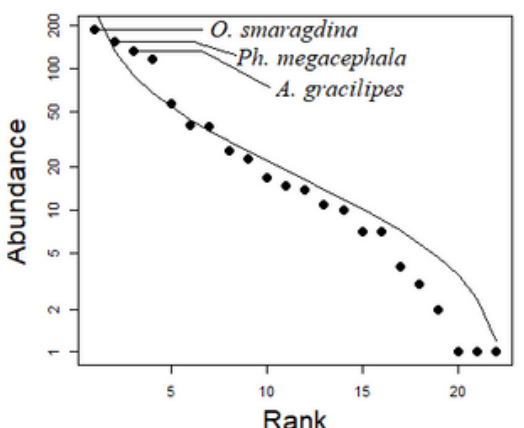

TAK

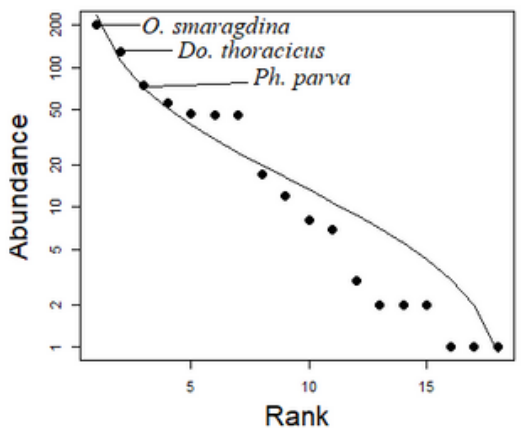

TDB

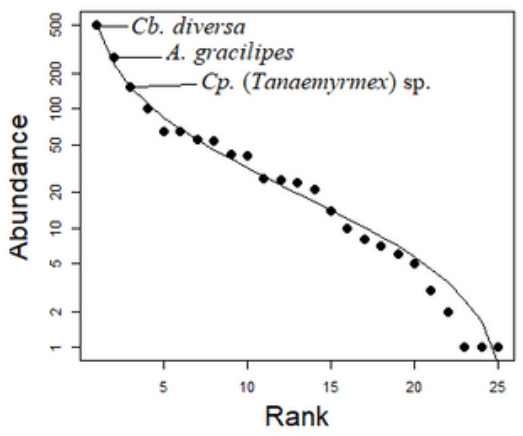

TMK

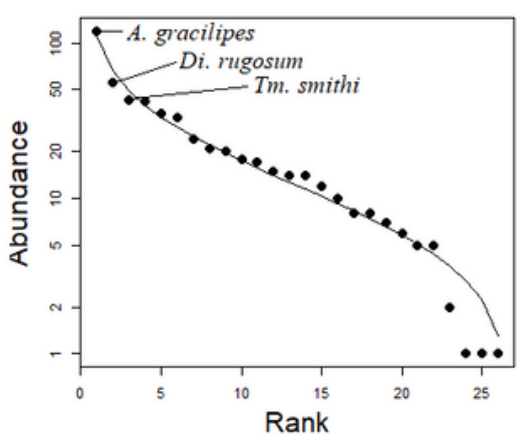

TTP

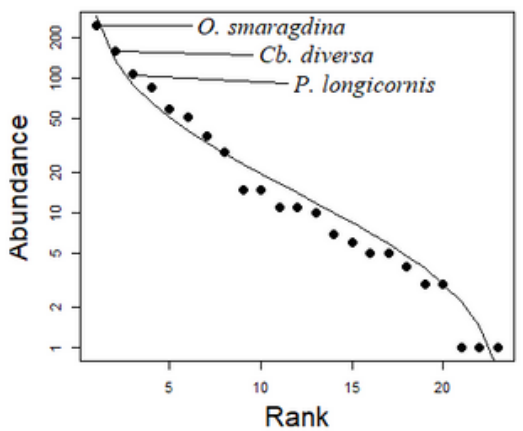

Figure 4

Rank-abundance plots of ants in urban parks, with top three species labelled in each plot. Abbreviations: A. $=$ Anoplolepis, $\mathrm{Cb} .=$ Carebara, $\mathrm{Cp} .=$ Camponotus, $\mathrm{Di} .=$ Diacamma, $\mathrm{Do} .=$ Dolichoderus, Mo. $=$ Monomorium, $\mathrm{O} .=$ Oecophylla, $\mathrm{Od} .=$ Odontoponera, $\mathrm{P} .=$ Paratrechina, $\mathrm{Ph} .=$ Pheidole, $\mathrm{Tm} .=$ Tetramorium 


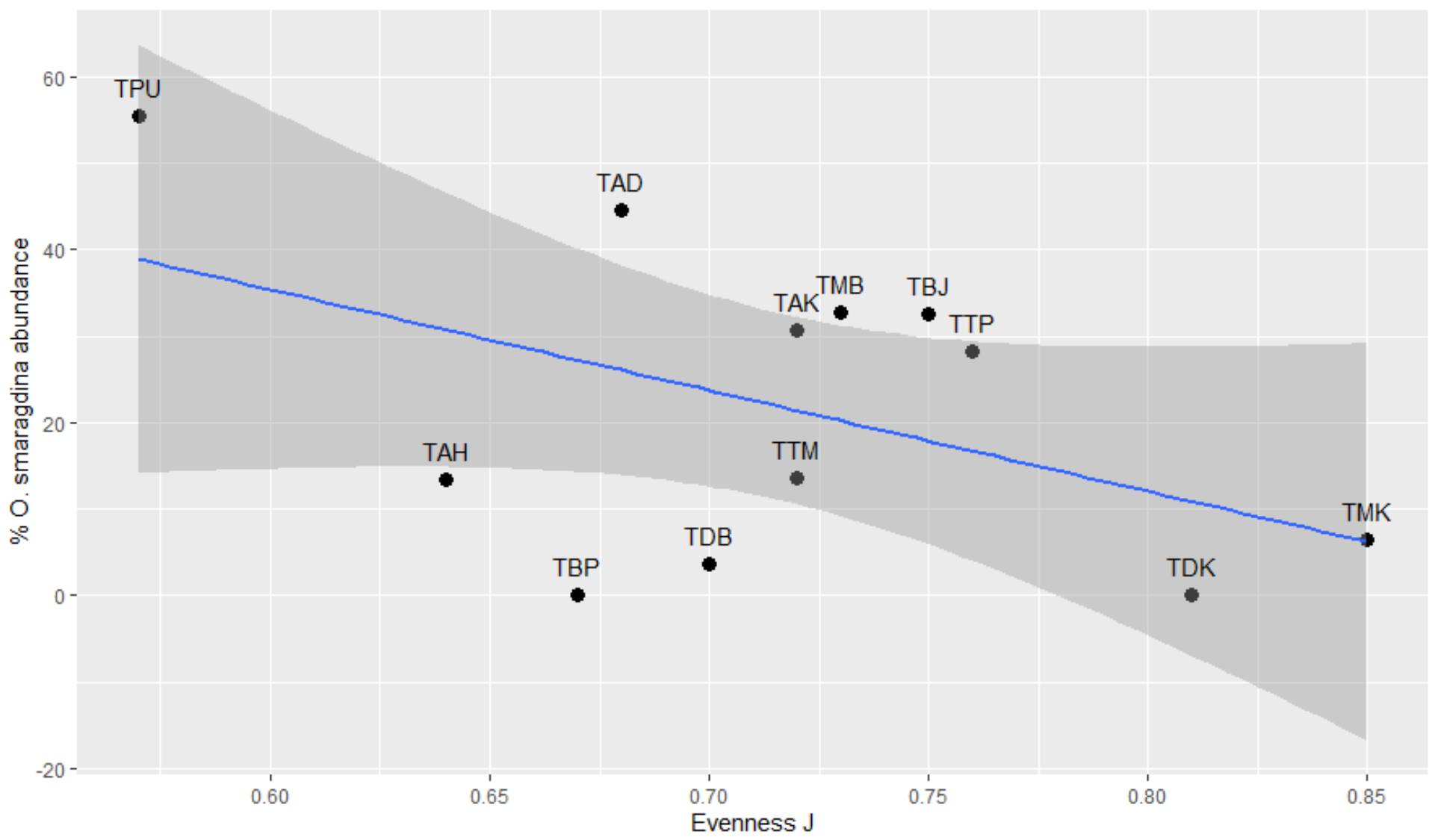

\section{Figure 5}

Linear regression model of the percentage abundance of $O$. smaragdina vs. Evenness $\mathrm{J}$ values in each park. Regression line indicated in blue and confidence interval at $95 \%$ indicated by the grey area 


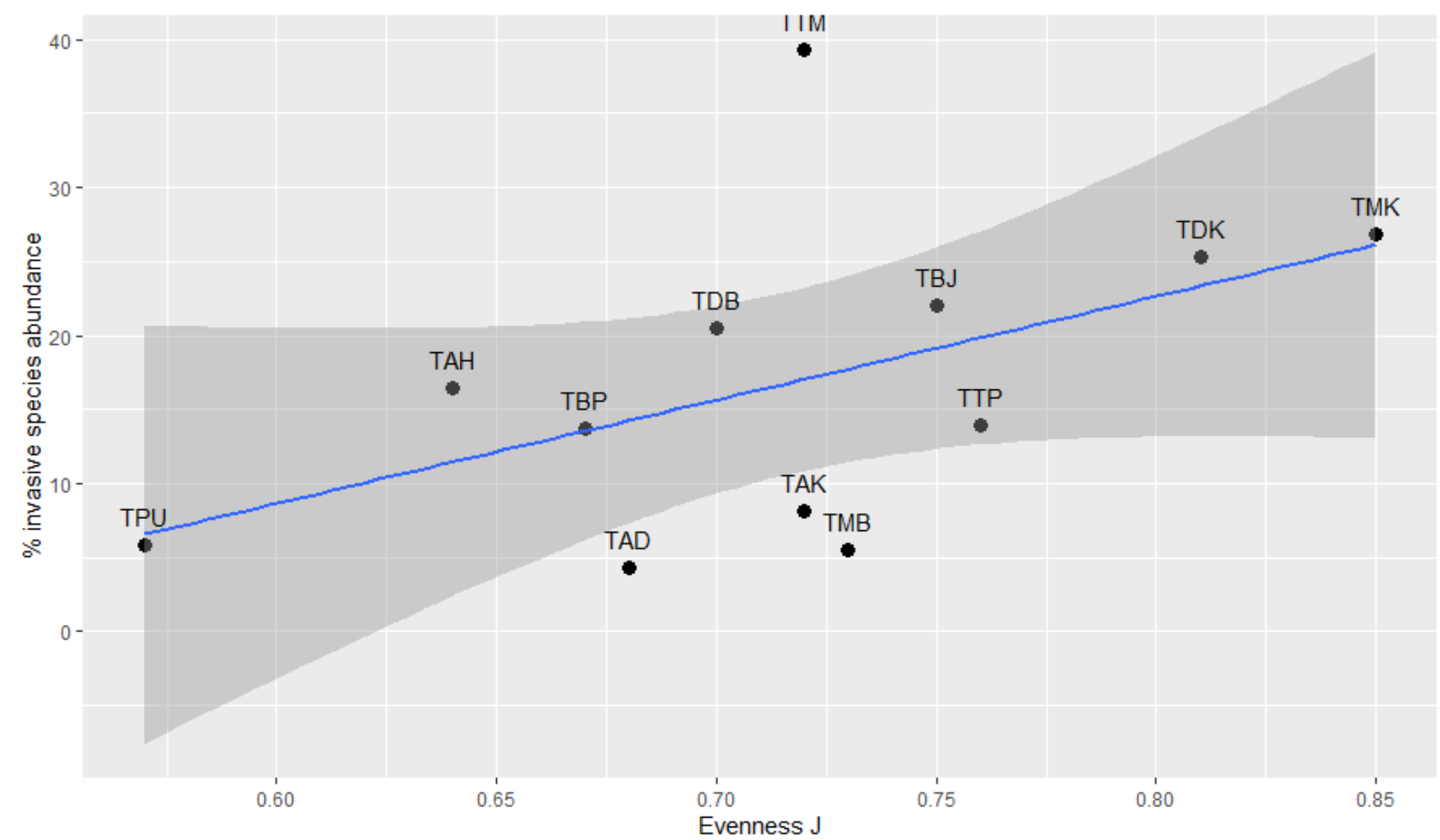

Figure 6

Linear regression model of the percentage abundance of invasive ants species vs. Evenness $\mathrm{J}$ values in each park. Regression line indicated in blue and confidence interval at $95 \%$ indicated by the grey area 